the twelfth magnitude.-From observations on Nov. 2 and 7 Herr Palisa has calculated circular elements of No. 153, which place the ascending node in longitude $228^{\circ} 3 \mathrm{I}^{\prime}$, with an inclination of $6^{\circ} 57^{\prime}$. The mean diurnal motion assigned on this hypothesis $\left(447^{\prime \prime}\right)$, if it were reliable, would make the period of this planet considerably longer than that of any other member of the group, but it will be necessary to wait till elliptical elements on a fair extent of observation are in our hands, before attributing to No. 153 a revolution so much in excess of the rest.

Publications.-(I) P. A. Hansen. Ueber die Storüngen der Grossen Planeten inbesondere des Fupiter. A posthumous memoir published in vol. xi. of the "Proceedings" of the Mathematical Class of the Royal Saxon Society of Sciences. The analytical developments forming the subject of the first part of this treatise are applied especially to the case of the planet Jupiter; the perturbations of latitude by Saturn, and the perturbations by Uranus, Neptune, Mars, the Earth, Venus, and Mercury are exhibited numerically; and from Herr v. Glasenapp, who was engaged in this part of the work up to the time of Prof. Hansen's decease, may, it is announced, be expected the complete calculation of the perturbations of longitude and radius-vector of Jupiter by Saturn.

(2) J. N. Stockwell. Theory of the Moon's Motion.-This is a republication in an extended form of an investigation which appeared in the Astronomische Nachrichten, Nos. 2,024-2,026, wherein the mathematical developments are given in greater detail, with the addition of those applying to the formulæ for latitude. The author hopes to find time to continue his investigations in the same direction, so as to complete the developments of the perturbations of the moon's motions by means of the differential equations given in this first chapter. In the author's introductory remarks on the labours of those eminent mathematicians who have taken up the lunar theory, in referring to Prof. Hansen, there is no mention of his "Fundamenta nova investigationis orbitæ veræ quam Luna perlustrat," Gotha, 1838; or his "Darlegung der Theoretischen Berechnung der in den Mondtafeln angewandten Storüngen," the first part of which appeared in 1862 , and the second in 1864 .

(3) Dr. Franz Melde. Theorie and Praxis der Astro. nomischen Zeitbestimmung, \&c. (Tübingen, 1875). - The author, Professor in the University of Marburg, explains that in the course of lectures on the determination of time by astronomical observations, he had found the want of a work in which the subject should be treated both in a theoretical and practical point of view, and in the present volume of 500 pages he has presented a very detailed discussion of time-determinations after the methods generally employed. The transit-instrument, its arrangement, mounting, and errors, with the methods of regulating it ; the sextant, more particularly as regards its use for ascertaining time by corresponding altitudes of sun or stars, time by occultations, refraction, aberration, precession, \&c., are explained at length. The volume, it will be seen, is one of a special character, and will be a desirable addition to an astronomical library.

\section{DR. R. VON WILLEMOES-SUHM}

$\mathrm{T} T$ is with the deepest regret that $I$ have to intimate the death of Dr. Rudolf von Willemoes-Suhm, at sea, on our passage from Hawaii to Tahiti. He had not been in his usual robust health for somemonths, having suffered occasionally from indolent boils on different parts of the body. On Sept. 6 he applied to the surgeon for advice. He had had a rather severe shivering fit the day before, and an inflamed spot on the face began to show symptoms of erysipelas. The swelling and inflammation of the face increased during the next week; it extended over the forehead; and the fever and delirium attending erysipelas became more pronounced. On the morning of Sept. I3 he sank into a state of collapse, and died at three o'clock in the afternoon.

This sad occurrence has of course thrown a heavy gloom over our little party. From the commencement of the voyage Dr. v. Willemoes-Suhm devoted himself with unremitting industry and zeal, and in the best possible spirit, to the objects of this expedition. He has already published, in connection with our work, a paper in the Annals and Magazine of Natural History, "On a terrestrial Nemertine from Bermudas;" a long paper in Linnean Proceedings, on the deep-sea Crustacea of the cruise ; "On the development of Umbellularia," in the Annals and Magazine: "On the Development of Lepas fascicularis," a paper sent to the Royal Society from Honolulu; and the notes on Crustacea which have been incorporated from time to time in my letters and reports. He has also written some interesting letters to Prof. von Siebold, describing the general zoological results of the cruise, which have been published in the Zeitschrift fiir Wissenschaftliche Zoologie. He leaves a fine series of drawings, with full descriptions, chiefly illustrating the development of surface Crustacea. For example, the development of species of the genera Euphausia, Sergestes, and Amphion is traced through all its stages. He leaves also an ample official journal in two large volumes. The loss of his valuable assistance in working up the final results of the expedition must, I fear, seriously affect their completeness.

Rudolf von Willemoes-Suhm was a native of SchleswigHolstein; his family now reside in the neighbourhood of Rendsburg, where his father holds a high official appointment. He was about twenty-eight years of age when he died. He studied in the Universities of Göttingen and Bonn; he showed very early a strong taste for natural history in all its branches, and when quite a boy he published papers on the habits of European birds. Shortly after he left the University, he was appointed PrivatDocent in Zoology in the University of Munich, where he was associated with Prof. von Siebold, with whom he was extremely intimate, and whose place he frequently took in the lecture-room when the professor was prevented from teaching by indisposition. In 1868 he visited Italy and made zoological observations at Spezzia. In the summer of 1870 he made a series of observations on various marine animals, Halicryptus, Balanoglossus, \&c. which formed the subject of his thesis on being appointed Privat-Docent in Munich.

In the summer of 1872 he went to the Faeroe Islands. He published some of the results of his investigations there in NATURE and elsewhere, but unfortunately a large series of zoological drawings which represented the greater part of his work was lost in transitu. It was from the accident of his calling upon me in Edinburgh, on his return from Faeroe, while there was still a vacancy on the staff of the Challenger, that he joined the expedition.

Among the more important of his publications are-

"Helminthologische Notizen," I. (Zeitschrift fur Wis. senschaftliche Zoologie, Bd. xix., 3 Heft.) Heft.)

Helminthologische Notizen," II. (Ibid. Bd. xx., I

"Zur Entwickelung von Schistocephalus dimorphus" (Ibid. Bd. xix., 3 Heft.)

"Biologische Beobachtungen über Niedere Thiere" (Leipzig, W. Engelmann, I87I) contains: "On a young calcareous sponge ;" "On the development of an appendiculate Distoma;" "On Balanoglossus kupferi," "On Halicryptus spinulosus;" "On Priapulus caudatus ;" "On the development of some Polychæte Annelids, Etone, Terebella, and Spirorbis;" "On the natural history of Polystoma integerrimum and of P. ocellatum."

Dr. von Willemoes-Suhm was a man of unusual acquirements and culture; besides having a wide and accurate knowledge of the literature of natural science, he 
was a good classical scholar, and could converse with perfect fluency in English, French, German, Danish, and Italian; and could read with ease nearly all the modern European languages. He made some strong friendships among his colleagues, and his acknowledged ability and his manner and address, which were eminently those of a polished gentleman and man of the world, won for him universal respect and esteem.

Altogether I looked upon Rudolf von WillemoesSuhm as a young man of the very highest promise, perfectly certain, had he lived, to have achieved a distinguished position in his profession, and I look upon his untimely death as a serious loss not only to the expedition in which he took so important a part, but also to the younger generation of scientific men among whom he was steadily preparing himself to become a leader.

H.M.S. Challenger, Tahiti, Oct. I

$$
\text { C. WYVILLE THOMSON }
$$

\section{THE PENIKESE SCHOOL}

$\mathrm{R}$ readers will regret to hear that the Anderson School of Natural History in Penikese Island, U.S., has come to an untimely end, and will no doubt regret still more that it has done so amid much unpleasant feeling between those chiefly concerned. We shall endeavour to state fairly the facts of the case.

$\mathrm{Mr}$. Anderson, who is a wealthy merchant, made a gift of Penikese Island and 50,000 dollars in cash to the late Prof. Agassiz, in order to enable him to start a school for the practical teaching of natural history. This sum, it may well be believed, was only sufficient to start the school, erect buildings, furnish apparatus, and other necessaries. No one can complain that Mr. Anderson did not also endow the school, and during the life-time of the elcler Agassiz there seems to have been no difficulty as to funds. On his death, his son, Mr. Alexander Agassiz, undertook to carry on the school. This he did, we believe, very unwillingly, as he knew there were no funds available for the daily business of the school, and he did not consider the island a suitable location for such an institution unless largely endowed. Moreover, it was his father's earnest wish that he should devote mosi of his time and energy to the Museum at Cambridge. However, he consented to conduct the school on condition that Mr. Anderson wculd contribute the sum of 10,000 dollars towards its support for the next three years. The first intimation of any dissatisfaction on the generous donor's part seems to have been made to the trustees at the end of 1874 , when he sent them $1329^{6} 60$ dollars to pay off debts which had been incurred, announcing at the same time that this was the last contribution he would make. The trustees seem, nevertheless, to have made every effort to carry on the school. A member of Prof. Agassiz's family contributed a guarantee fund of 3,000 dollars, and appeals were made in all directions, but without anything like success. Clearly the trustees and the teachers themselves could not be expected to carry on the school at their own expense, and all that they had any right to look for from Mr. Anderson was the balance of the 10,000 dollars which he promised; why he failed to contribute this, we are unable to say. Had he done so, those interested in the success of the school would have had time to set about raising something like an endowment fund, and a fine opportunity would have been afforded to the U.S. Government to show their appreciation of practical scientific teachers and scientific research. As it was, the only course which seemed left to the trustees, when everything is taken into account, was to close the school and sell off the furniture and aquaria. Mr. Anderson seems to have considered himself ill used and insulted by the trustees, and Mr. Agassiz in particular; but so far as the facts are known to us, we certainly believe he is mistaken. Mr. Agassiz has duties of the highest importance to attend to in connection with the Cambridge Museum, and he could not possibly be expected to waste his time and energy on an undertaking in whose success no one seemed to be interested. He seems to us to have acted in a straightforward and honourable manner, and only to have given up the school when he saw there was no possible hope of getting funds to carry it on. Mr. Anderson, for some reason which does not appear, seems to have lost his temper, and may naturally have been annoyed that the public did not come forward in support of the school which he so generously founded. The result is certainly to be regretted, but we hope that Mr. Agassiz and Mr. Anderson may come to a better understanding, and that even if the school be not again started, the latter will see that the former has acted all along in the interests of science, whose servant he is. To have touched the Agassiz Memorial Fund, now 347,000 dollars, as some one sug gested should have been done, was simply impossible; it was collected for a special purpose.

Mr. Agassiz took two of the most promising Penikese pupils into his laboratory at Newport, and intends, we believe, as soon as the necessary means can be collected, to establish a school at some more suitable locality.

\section{THE THEORYOF"STREAM LINES" INRELA.} TION TO THE RESISTANCE OF SHIPS *

\section{II.}

I T might at first sight appear that I have now the materials for the proof of my chief proposition, the assertion of the unresisted progress of a submexgerl body ; for such a body might be assumed to be surrounded by a system of imaginary pipes, as shown in Fig. 8; and each of these pipes heing in equilibrium

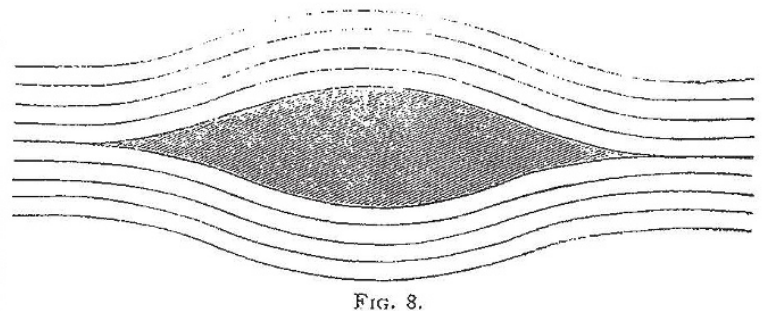

endways, that is to say, the flow of fluid through it not tending in the aggregate to move it end ways, neither, it might be said, would the fow of fluid tend to move the submerged body endways. But this reasoning would not be sound. The pipes we have hitherto been considering have been of uniform sectional area throughout their length, an assumption which has been necessary to the treatment pursued, as the velocity has in each case been assumed to be uniform throughout the pipe. The section of the pipe may have been square, circular, trapezoidal, or any other form; but the area of the section has been assumed to be the same throughout the length of the pipe.

But pipes of uniform sectional area do not truly represent the flow of a fluid past a submerged body. I shall presently ask you to consider the fluid as flowing past the body through a system of imaginary pipes; but to render the assumption admissible, the sides of the imaginary pipes must not be so placed as to interfere with the established course of the fluid, whatever that may be ; in other words, if, for the sake of illustrating the behaviour of the fluid, we assume that it is divided into streams or filaments flowing through imaginary pipes, we must accept such a form for those imaginary pipes that their sides exactly follow the paths of the adjacent particles of fluid.

Now such a rule may, and probably will, require the imaginary pipes to be of varying sectional area throughout their length. Therefore, before we can apply the analogy of the flow of fiuid through pipes to the flow of a fluid past a submerged body, it is necessary to consider the behaviour of fluid in pipes of varying sectional area.

It is, I think, a very common but erroneous impression, that a * Address to the Mechanical Section of the British Association, Bristol, August $25, x 875$; by William Froude, C.E., M.A., F.R.S. President the Section. Revised and extended by the author. Continued from p. $5^{2}$. 